\title{
Watermelon transformation with Zucchini yellow mosaic virus coat protein gene and comparison with parental cultivar
}

\author{
Sebahattin Çürük ${ }^{(1)}$ and Ebru Meşe ${ }^{(1)}$ \\ (1)Mustafa Kemal University, Faculty of Agriculture, Department of Horticulture, TR-31034 Antakya-Hatay, Turkey. \\ E-mail: sebahattincuruk@gmail.com, ebrum1607@hotmail.com
}

\begin{abstract}
The objective of this work was to transfer Zucchini yellow mosaic virus coat protein (ZYMV-CP) and neomycin phosphotransferase II (NPT II) genes to the watermelon 'Crimson Sweet' (CS) genome, and to compare the transgenic progenies T1 and T2 with the nontransformed parental cultivar for morphological, pomological, growth and yield characteristics. The ZYMV-CP gene was transferred by Agrobacterium tumefaciens. The presence of the gene in transgenic T0, T1 and T2 plants was determined by polymerase chain reaction, and the results were confirmed by Southern blot. Two experiments were performed, one in the winter-spring and the other in the summer-autumn. In both experiments, the hypocotyl length of transgenic seedlings was significantly higher than that of nontransgenic parental ones. In the second experiment, the differences between transgenic and nontransgenic individuals were significant concerning fruit rind thickness, flesh firmness, fruit peduncle length, size of pistil scar, and a* values for fruit stripe or flesh color. Transferring ZYMV-CP gene to CS genome affected only a few characteristics from the 80 evaluated ones. The changes in rind thickness, flesh firmness and flesh color a* values are favorable, while the increase in the size of pistil scar is undesirable. The transgenic watermelon line having ZYMV-CP gene and the parental cultivar CS are very similar.
\end{abstract}

Index terms: Citrullus lanatus, comparative safety analysis, genetic modification, neomycin phosphotransferase II, nontransgenic watermelon, transgenic watermelon.

\section{Transformação de melancia com o gene da capa proteica do Zucchini yellow mosaic virus e comparação com a cultivar parental}

Resumo - O objetivo deste trabalho foi transferir o gene da capa proteica do Zucchini yellow mosaic virus (ZYMV-CP) e o gene neomycin phosphotransferase II (NPT II) para o genoma da melancia 'Crimson Sweet' (CS), e comparar as progênies T1 e T2 com a cultivar parental não transformada, quanto às características morfológicas, pomológicas, de crescimento e de produção. O gene ZYMV-CP foi transferido por meio da transformação com Agrobacterium tumefaciens. A presença do gene nas plantas transgênicas T0, T1 e T2 foi determinada pela reação de polimerase em cadeia, e os resultados foram confirmados pelo "Southern blot". Dois experimentos foram realizados, um no inverno-primavera e outro no verão-outono. Nos dois experimentos, o comprimento do hipocótilo das plântulas transgênicas foi significativamente maior do que nas plântulas não transgênicas. No segundo experimento, as diferenças entre as plantas transgênicas e não transgênicas foram significativas quanto à espessura da casca das frutas, firmeza da polpa, comprimento do pedúnculo, tamanho da cicatriz do pistilo, e valores a* da cor das listras ou da polpa. A transferência do gene da capa proteica ZYMV-CP ao genoma CS afetou apenas algumas características, das 80 avaliadas. As alterações na espessura da casca, firmeza e cor da polpa são favoráveis, enquanto o aumento no tamanho da cicatriz do pistilo é indesejável. A linhagem transgênica de melancia com o gene ZYMV-CP e a cultivar parental CS são muito similares.

Termos para indexação: Citrullus lanatus, análise de segurança comparativa, modificação genética, neomycin phosphotransferase II, melancia não transgênica, melancia transgênica.

\section{Introduction}

Transgenic crop production in the world is increasing. The leading countries in transgenic crop production are USA (66.8 million ha), Brazil (25.4 million ha), Argentina (22.9 million ha), India (9.4 million ha), Canada ( 8.8 million ha) and China (3.5 million ha) (International Service for the Acquisition of Agri-Biotech Applications, 2010). The concepts of substantial equivalence or comparative safety analysis are accepted for transgenic crop safety assessment (Organisation for Economic Co-Operation and Development, 1993; Food and Agriculture Organization, 1996; Barros et al., 2010). Since concerns over the transgenic crops safety raised, comparisons of transgenic crop compositions and performances with

Pesq. agropec. bras., Brasília, v.47, n.1, p.66-75, jan. 2012 
those of conventionally bred crops, under field and protected cultivation, have been detailed (Shewry et al., 2007). In this sense, the genetically modified crop is compared to its conventional genotypes for agronomic and phenotypic variation, and by compositional analysis which includes analysis of macro- and micronutrients, as well as of toxins and antinutrients (Barros et al., 2010).

There are several reports for detailed comparisons of genetically modified crops and those of conventional counterparts in cereals. According to Venneria et al. (2008), no significant differences were observed for qualitative traits analyzed in wheat and corn as fatty acids content, unsaponifiable fraction of antioxidants, total phenols, polyphenols, carotenoids, vitamin C, total antioxidant activity, and mineral composition. It was reported that the effect of transgenesis on transcriptome was lower than that of conventional breeding concerning the wheat grain (Baudo et al., 2006; Shewry et al., 2007; Ammann, 2011). Batista et al. (2008) have concluded that plant mutagenesis may induce more transcriptomic changes than transgene insertion in rice. Coll et al. (2009) showed that gene expression profiles of transgenic maize plants MON810 and its near-isogenic nontransgenic maize genotypes were more similar than those of conventional lines. According to Barros et al. (2010), the differences in transcript/protein/metabolite profiles between locations (environment) were higher than the difference between Bt-maize and nontransgenic cultivar, and growing seasons had a stronger overall effect in the transcriptome, proteome and metabolome of the maize genotypes than the genetic modification.

To our knowledge, unlike cereals, there are a few reports comparing transgenic and their nontransgenic originating conventional cultivars in fruit and vegetable crops. Catchpole et al. (2005) reported that except for targeted traits, genetically modified potatoes appear substantially equivalent to traditional cultivars. According to Jiao et al. (2010), the composition in transgenic papayas exhibited great similarity to the one in nontransgenic counterparts. Venneria et al. (2008) showed that genetically modified events are nutritionally similar to conventional tomato varieties. Yalçın-Mendi et al. (2010) have reported that there was no significant difference between transformed (with ZYMV-CP) melon line and nontransformed control cultivar, except for fruit total acidity. However, there are no reports on the detailed comparison of transgenic watermelon [Citrullus lanatus (Thunb.) Matsum. \& Nakai] line with its nontransgenic originating cultivar.

The objective of this study was to transfer Zucchini yellow mosaic virus coat protein (ZYMV-CP) and neomycin phosphotransferase II (NPT II) genes to watermelon cultivar Crimson Sweet (CS) genome, and to compare the transgenic $\mathrm{T} 1$ and $\mathrm{T} 2$ generations with nontransformed plants of the same cultivar (parental cultivar) for morphological, pomological, growth and yield characteristics.

\section{Materials and Methods}

Nontransgenic watermelon cultivar Crimson Sweet - CS (Bursa tohumculuk A.Ş., Turkey) was used. For genetic transformation, watermelon seed coats were removed, and the seeds were washed in $70 \%$ ethanol for $5 \mathrm{~min}$, rinsed three times with sterile distilled water, and surface-disinfected in a solution of $1.2 \%$ sodium hypochlorite with two drops of Tween 20 per $100 \mathrm{~mL}$, for $40 \mathrm{~min}$. After rinsing, seeds were further washed for $15 \mathrm{~min}$ in $500 \mathrm{mg} \mathrm{L}^{-1}$ cefotaxime. MS medium (Murashige \& Skoog, 1962) was used for seed germination in a growth room at $27 \pm 1^{\circ} \mathrm{C}$, in the dark. Cotyledons were excised from four-day-old seedlings and cut across to make two explants per cotyledon, and then were trimmed along all edges. Diferent media were used for regeneration, shoot elongation and rooting, as follows: RM-MS salts, modified MS vitamins, $30 \mathrm{~g} \mathrm{~L}^{-1}$ sucrose, $2.25 \mathrm{mg} \mathrm{L}^{-1} \mathrm{BA}$, as in Compton \& Gray (1993); SE-MS salts, modified MS vitamins, $20 \mathrm{~g} \mathrm{~L}^{-1}$ sucrose; and SR-MS salts, modified MS vitamins, $20 \mathrm{~g} \mathrm{~L}^{-1}$ sucrose, $0.186 \mathrm{mg} \mathrm{L}^{-1} \mathrm{NAA}$ or $250 \mathrm{mg} \mathrm{L}^{-1}$ cefotaxime. Media were solidified with $8 \mathrm{~g} \mathrm{~L}^{-1}$ agar, and sterilized at $121^{\circ} \mathrm{C}$ for $15 \mathrm{~min}$. In vitro cultures were incubated at $27 \pm 1^{\circ} \mathrm{C}$, with a 16 -hour photoperiod of $60-70 \mu \mathrm{mol} \mathrm{m} \mathrm{m}^{-2} \mathrm{~s}^{-1}$ photon flux during regeneration-selection, elongation-selection and rooting.

Agrobacterium tumefaciens strain EHA 105 having the plasmid pCIB10, which contained NPT II and ZYMV-CP genes (Fang \& Grumet, 1993), was used for transformation. A colony of this bacterium was incubated for 18 hours in $2 \mathrm{~mL}$ liquid LB medium Merck, VM491085542 (Merck, Gibbstown, NJ, USA), with $50 \mathrm{mg} \mathrm{L}^{-1}$ kanamycin at $28 \pm 1{ }^{\circ} \mathrm{C}$, and shaken at 125-140 rpm. The generated culture was stored at 
$-80^{\circ} \mathrm{C}$ after the addition of $174 \mu \mathrm{L}$ dimethyl sulfoxide. Two hundred microliters of this culture were added to $2 \mathrm{~mL}$ of liquid LB with $50 \mathrm{mg} \mathrm{L}^{-1}$ kanamycin, and shaken (as above) for 5 hours. Then, the culture was added to $40 \mathrm{~mL}$ liquid $\mathrm{LB}$, without antibiotics, prior to inoculation. Approximately $10 \mathrm{~mL}$ of this diluted culture were used for inoculation of 100 cotyledon explants. The cotyledons of seedlings were transferred to the Agrobacterium culture in a sterile Petri dish. The explants were excised in the Agrobacterium culture (approximately $10 \mathrm{~min}$ ), inoculated for $10 \mathrm{~min}$ with occasional agitation, and then distributed on RM medium without antibiotics, and co-cultivated for two days in the growth room in the dark. Then, they were washed three times with sterile distilled water, and placed in 90x15-mm Petri dishes (approximately 20 explants per dish) with the adaxial side onto RM medium containing $75 \mathrm{mg} \mathrm{L}^{-1}$ kanamycin and $400 \mathrm{mg} \mathrm{L}^{-1}$ timentin (Research Triangle Park, Durham, NC, USA), and cultured for three weeks. The explants were subcultured for three weeks in the RM medium with $100 \mathrm{mg} \mathrm{L}^{-1}$ kanamycin and the same concentration of timentin.

Regenerating parts of the explants were excised and transferred to SE medium with $125 \mathrm{mg} \mathrm{L}^{-1}$ kanamycin and $400 \mathrm{mg} \mathrm{L}^{-1}$ timentin, and cultured for six weeks, at three-week intervals. To stimulate root formation, shoots growing on kanamycin were first transferred to SR medium in test tubes $(25 \times 150 \mathrm{~mm})$ and incubated for two weeks. Then, the shoots were rooted on SR medium without NAA, but supplemented with $250 \mathrm{mg} \mathrm{L}^{-1}$ cefotaxime, which stimulates root formation (Çürük et al., 2005). Test tubes which had the putative transformants were gradually opened in the growth room, and the plants were transplanted to the plastic pot containing $0.2 \mathrm{~L}$ substrate, composed of $66 \%$ peat Potgrond H (Klasmann-Deilmann, GmbH, Geeste, Germany) and 34\% perlite.

For ZYMV-CP gene detection, polymerase chain reaction (PCR) was performed. One hundred miligrams of plant tissue were grinned in liquid nitrogen, and DNA was isolated (Gusmini \& Wehner, 2010). For each sample, $4 \mu \mathrm{L}$ suspended DNA (approximately $100 \mathrm{ng}$ ) were used for $21 \mu \mathrm{L}$ reaction mixture. The reaction mixture was composed of $2.5 \mu \mathrm{L}$ PCR buffer (x10), $1.5 \mu \mathrm{L}$ of $25 \mathrm{mmol} \mathrm{L}^{-1}$ $\mathrm{MgCl}_{2}, 0.5 \mu \mathrm{L}$ of $10 \mathrm{mmol} \mathrm{L}^{-1} \mathrm{dNTPs}, 14.3 \mu \mathrm{L}$ double distilled water, $1 \mu \mathrm{L}$ each of primer $1\left(5 \mu \mathrm{mol} \mathrm{L} \mathrm{L}^{-1}\right.$,
5'-AAGTCTAGAAAATAACAAATCTCAACA-3') and primer $\quad 2 \quad\left(5 \quad \mu m o l \quad \mathrm{~L}^{-1}\right.$, 5'-AATGAGCTCTTTTTTTTTAGGCTTG-3'), and $0.2 \mu \mathrm{L}$ Taq DNA polymerase (Fermentas, Vilnius, Lithuania). In the PCR reaction, final concentrations of PCR buffer, $\mathrm{MgCl}_{2}$, dNTPs, primers, and Taq DNA polymerase were $\mathrm{x} 1,1.5 \mathrm{mmol} \mathrm{L}^{-1}, 200 \mu \mathrm{mol} \mathrm{L}^{-1}$ (each

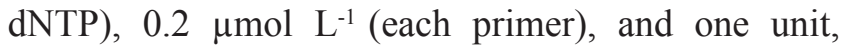
respectively. Each PCR reaction consisted of an initial denaturation at $95^{\circ} \mathrm{C}$ for 2 min ( 1 cycle), and denaturation at $95^{\circ} \mathrm{C}$ for $45 \mathrm{~s}$, annealing at $50^{\circ} \mathrm{C}$ for $1 \mathrm{~min}$, extention at $72^{\circ} \mathrm{C}$ for $90 \mathrm{~s}$ (30 cycles), and a final extention at $72^{\circ} \mathrm{C}$ for $5 \mathrm{~min}$ ( 1 cycle).

The presence of ZYMV-CP gene in PCR-positive plants, and the absence of the gene in nontransgenic parental plants were detected by Southern blot. For Southern blot analysis, a nonradioactive probe of ZYMV-CP gene was prepared. The pCIB10 plasmid was isolated from $5 \mathrm{~mL}$ Agrobacterium culture that was grown for 20 hours under the mentioned conditions, combining the protocol by Helms (1990) and Spin Columns of GeneJET Plasmid Miniprep Kit (Fermentas, Vilnius, Lithuania). The ZYMV-CP gene (approximately $1.2 \mathrm{kbp}$ ) was amplified by PCR with $1 \mu \mathrm{L}$ of suspended plasmid DNA (30 ng). The PCR product was run on $0.8 \%$ agarose gel, and the ZYMV-CP gene was gel-extracted following the manufacturer's instructions Silica Bead DNA Gel Extraction Kit\#K0513 (Fermentas, Vilnius, Lithuania). The gel-extracted DNA was labeled using DIG High Prime DNA Labeling and Detection Starter Kit II (Roche Diagnostics GmbH, Mannheim, Germany) following the manufacturer's recommendations.

For Southern blot analysis, DNA was prepared from watermelon leaves (Levi \& Thomas, 1999). Approximately $10 \mu \mathrm{g}$ of genomic DNA was restriction-digested with $X b a \mathrm{I}$, following the manufacturer's instructions, (Fermentas, Vilnius, Lithuania), run on $1 \%$ agarose gel at $30 \mathrm{~V}$ for 8 hours, and blotted onto a charged nylon membrane NP0HY00010 (GE Infrastructure Water \& Process Technologies, Vista, CA, USA), using a vacuum blotter 785 (BIO-RAD, Hercules, CA, USA). DIG-labeled ZYMV-CP probe and blots of restriction-digested watermelon DNA onto charged nylon membrane were hybridized, washed and detected according to the manufacturer's manual Roche, 11585614910 (Roche, Maslak, Istanbul, Turkey). The membrane was 
prehybridized in DIG Easy Hyb for 30 min at $44^{\circ} \mathrm{C}$, with gentle agitation at $14 \mathrm{rpm}$ in a hybridization oven HB-1000 Hybridizer, UVP (Laboratory Products, Cambrige, UK). The DIG-labeled ZYMV-CP probe which had been stored at $-20^{\circ}$ was denaturated by incubation in boiling water for $5 \mathrm{~min}$ and, then, by rapidly cooling in ice-water for $2 \mathrm{~min}$. After that, the membrane was hybridized with this probe for four hours or overnight at $44^{\circ} \mathrm{C}$ and $14 \mathrm{rpm}$. After hybridization, the wash procedure of the nylon membrane was carried out in two steps. In the first step, the membrane was washed twice with a $2 \mathrm{xSSC} / 0.1 \%$ SDS solution, for $5 \mathrm{~min}$ at $15-25^{\circ} \mathrm{C}$, under constant agitation at 20 $30 \mathrm{rpm}$. In the second step, it was washed twice with a $0.5 \times \mathrm{xSC} / 0.1 \% \mathrm{SDS}$ solution for $15 \mathrm{~min}$ at $67^{\circ} \mathrm{C}$. All the incubations made for detection were performed at $30^{\circ} \mathrm{C}$ with agitation at $40-50 \mathrm{rpm}$. The membrane was agitated in washing buffer $\left(0.1 \mathrm{~mol} \mathrm{~L}^{-1}\right.$ maleic acid, $0.15 \mathrm{~mol} \mathrm{~L}^{-1} \mathrm{NaCl}$ (pH:7.5), 0.3\% Tween 20), and incubated for $40 \mathrm{~min}$ in a blocking solution and $30 \mathrm{~min}$ in an antibody solution; then, it was washed again twice with the washing buffer for $20 \mathrm{~min}$. After that, the membrane was equilibrated for $5 \mathrm{~min}$ in detection buffer (0.1 mol L-1 Tris-HCl, $\left.0.1 \mathrm{~mol} \mathrm{~L}^{-1} \mathrm{NaCl}, \mathrm{pH}: 9.5\right)$. Then, $1 \mathrm{~mL}$ of CSPD ready-to-use was applied on the membrane. Hybridization signals were detected by exposing the membrane to an X-ray film at $15-25^{\circ} \mathrm{C}$ for $60 \mathrm{~min}$.

According to the growth of the putative transgenic shoots on selection medium supplemented with kanamycin, and to PCR analysis, four transformation events were obtained from transformation experiments. In vitro regenerated plants from one of these events, which were morphologically the most similar to their parental cultivar, were selected as primary transgenic (T0). Then, the seeds of $\mathrm{T} 1$ generation were obtained by self-pollination of T0 plants. Transgenic T1 plants were selected by PCR for transgene ZYMV-CP. The seeds of $\mathrm{T} 2$ generation were similarly produced by self-pollination of the PCR-positive plants of $\mathrm{T} 1$ generation. The transfer of the genes was confirmed by Southern blot detection in $\mathrm{T} 1$ and $\mathrm{T} 2$ generations. The growth and self-pollination of the plants were carried out in the glasshouse, and described as follows.

To compare transgenic and nontransgenic watermelon genotypes, two experiments were carried out in the winter-spring (first experiment) and summer-autumn (second experiment) growing seasons in 2009, at the Agricultural Research Station of Mustafa Kemal University, Antakya, in the Southeastern Mediterranean Region of Turkey. Plants were grown in a glasshouse with steel structure, with $10 \mathrm{~m}$ span width, $4 \mathrm{~m}$ gutter height, $5.5 \mathrm{~m}$ ridge height, continuous roof ventilation windows $(2 \times 10 \mathrm{~m})$ and two exhaust fans. The ventilation windows of the glasshouse were closed with a 50 -mesh net. The exhaust fans were on, when the inside temperature was higher than $28^{\circ} \mathrm{C}$. The glasshouse was heated with a radiator using the central heating system, when the inside temperature was lower than $17^{\circ} \mathrm{C}$. When air temperature in the glasshouse was higher than $35^{\circ} \mathrm{C}$, an inside screen XLS 15 Firebreak (AB Ludving Svenson, Sweden) was used to reduce the temperature. Nontransformed CS and T1 (transgenic) seeds for the first experiment, and nontransformed CS and T2 (transgenic) seeds for the second experiment were sown in the aforementioned substrate, in January 10 and July 18 of 2009, respectively. The PCR-negative plants of nontransformed CS, and the positive ones of transgenic generations were transplanted to plastic pots containing $16 \mathrm{~L}$ of the mentioned substrate, and grown in the glasshouse at a density of 1.33 plants $\mathrm{m}^{-2}$ $(1.5 \times 0.5 \mathrm{~m})$.

The experiment was performed in a completely randomized design, with three replicates per treatment and 10 plants per replicate. Unless otherwise noted, measurements were made on eight plants per replicate. The plants were irrigated by hand as needed. The total amount of applied $\mathrm{N}-\mathrm{P}_{2} \mathrm{O}_{5}-\mathrm{K}_{2} \mathrm{O}$ was $200-120-300 \mathrm{~kg} \mathrm{ha}^{-1}$. Since insect activity was very low due to the net use (with 50 meshes) on the ventilation windows, the flowers were self-pollinated to obtain fruit. During the first experiment, average minimum and maximum air temperatures inside the glasshouse were approximately 15.7 and $30.6^{\circ} \mathrm{C}$ in January, 18.2 and $30.3^{\circ} \mathrm{C}$ in February, 19.5 and $32.1^{\circ} \mathrm{C}$ in March, 21.3 and $37.3^{\circ} \mathrm{C}$ in April. In the second experiment, the average minimum and maximum temperatures were approximately 28.1 and $41.1^{\circ} \mathrm{C}$ in July, 26.8 and $38.5^{\circ} \mathrm{C}$ in August, 22.6 and $35.4^{\circ} \mathrm{C}$ in September, 20.0 and $35.2^{\circ} \mathrm{C}$ in October, 20.0 and $27.2^{\circ} \mathrm{C}$ in November. The photoperiod during both experiments was the natural daylength.

The measurements of hypocotyl and cotyledon length $(\mathrm{cm})$ and width $(\mathrm{cm})$, and the observation (absent or spotted) of cotyledon spotty status were made in January 26 and July 26 of 2009, in the first 
and second experiments, respectively. Stem thickness $(\mathrm{mm})$, main stem length $(\mathrm{cm})$, and number of branches and nodes in the main stem were determined three weeks before harvest. Measures were performed on two fully developed leaves of each plant for petiole length $(\mathrm{cm})$, and for blade width $(\mathrm{cm})$ and length (cm), and observations were done for blade blistering or spotting (absent or present), being the leaf blade secondary lobing classified as weak (3), intermediate (5) or strong (7), according to the International Union for the Protection of New Varieties of Plants (2004)

From each replicate, two plants at flowering were used for the measurements of fresh and dry weigh $(\mathrm{g})$, and leaf area $\left(\mathrm{cm}^{2}\right.$ per plant), using a leaf area meter Li-cor 3100 (Li-cor, Lincoln, NE, USA). The leaves, roots and stems-branches of the plants were weighted separately, before and after drying at $65^{\circ} \mathrm{C}$ for two days. Node number of the first male and female flower, and time (day) of male and female flowering were recorded. Leaf and flower measurements or observations were made on two leaves or flowers per plant from each replicate. For pomological analysis, seven or eight fruit were used in each replicate. Petal width $(\mathrm{mm})$ of male, and petal height $(\mathrm{mm})$, and ovary length $(\mathrm{mm})$ and width $(\mathrm{mm})$ of female flowers were measured. Petal apex shape of female flower (acute, 3; rounded, 5; obtuse, 7) according to TC Resmi Gazete (1998), and pubescence of the ovary (weak, 3; intermediate, 5; strong, 7) as per the International Union for the Protection of New Varieties of Plants (2004) were determined. Pollen viability (\%) was determined using $1 \%$ triphenyl tetrazolium chloride. Pollens were germinated in a medium containing $20 \%$ sucrose, $100 \mathrm{mg} \mathrm{L}^{-1} \mathrm{H}_{3} \mathrm{BO}_{3}$, $300 \mathrm{mg} \mathrm{L}^{-1} \mathrm{Ca}\left(\mathrm{NO}_{3}\right)_{2} \cdot 4 \mathrm{H}_{2} \mathrm{O}, 200 \mathrm{mg} \mathrm{L}^{-1} \mathrm{MgSO}_{4} \cdot 7 \mathrm{H}_{2} \mathrm{O}$, $100 \mathrm{mg} \mathrm{L}^{-1} \mathrm{KNO}_{3}$ and $0.2 \%$ agar (Şensoy et al., 2003).

Fruit weight $(\mathrm{kg})$, length $(\mathrm{cm})$, and width $(\mathrm{cm})$ were measured at maturity. Fruit shape (flattened, 1; round, 2; broad elliptical, 3; elliptical, 4; pyriform, 5; oblong, 6) was classified in conformity with the European Cooperative Programme for Plant Genetic Resources (2008). Shape of apical and basal parts of the fruit (flat, 1; flat to rounded, 2; rounded, 3; rounded to conical, 4; conical, 5) were recorded according to TC Resmi Gazete (1998) and the International Union for the Protection of New Varieties of Plants (2004). Grooves and marbling on fruit were observed as absent or present. Flesh firmness was measured in newtons (N), using a penetrometer (Nippon Optical Works Ca,
LTD, Tokyo, Japan) fitted with a $5 \mathrm{~mm}$ diameter probe, and fruit rind thickness $(\mathrm{mm})$ were determined. Fruit peduncle length $(\mathrm{cm})$ and diameter $(\mathrm{mm})$, and insertion size of peduncle $(\mathrm{mm})$ were measured just before harvest. Number of seeds per fruit, and size of pistil scar $(\mathrm{mm})$ were recorded. The watermelon fruit quality properties, namely malic acid (\%) (Sadler, 1994), $\mathrm{pH}$ and total soluble solid ( ${ }^{\circ}$ Brix) (Çürük et al., 2009), were measured. Ground and stripe colors of fruit skin, and colors of fruit flesh and leaf blade were determined according to Cielab ( $\left.\mathrm{L}^{*} \mathrm{a} * \mathrm{~b} *\right)$ colour space, using a Chroma Meter Minolta CR-300 (Minolta, Osaka, Japan), and $\mathrm{L}^{*}, \mathrm{a}^{*}, \mathrm{~b}^{*}, \mathrm{C}^{*}, \mathrm{~h}^{\mathrm{o}}$ values were recorded (McGuire, 1992).

The ploidy levels of nontransgenic and transgenic T0 plants of CS were analyzed by flow cytometry, using leaf samples (Arumuganathan \& Earle, 1991). The ploidy level (diploid, triploid or tetraploid) of transgenic $\mathrm{T} 1$ or T2 plants were determined observing flower, leaf, pollen and seed characteristics. Reproductive system (monoecious or andromonoecious) and plant growth habit (bushy or runner) were recorded. Seed characteristics, namely mean weight (mg per seed), testa ground color, and patches at hilum, were determined. Total yield $\left(\mathrm{kg} \mathrm{m}^{-2}\right)$ was taken from each plot and weighted on a weekly basis once fruit began to ripen.

Data analyses were performed by using SAS (SAS Institute, 1999). Data were subjected to a general linear model analysis (GLM) ANOVA, and means were compared by the least significant difference (LSD) test.

\section{Results and Discussion}

The flow cytometry analysis showed that the ploidy levels of nontransformed and transgenic T0 plants were diploid.The PCR detection showed that T0, T1 and T2 plants had the ZYMV-CP gene (Figure $1 \mathrm{~A}$ ), and none of the nontransformed control plants contained the gene. In T1 and T2 populations, 71\% (57/80) and $83 \%(50 / 60)$ of the plants (respectively) contained the ZYMV-CP gene according to PCR amplification.

Since $X b a \mathrm{I}$ only cuts on one side of the ZYMV-CP gene, the other $X b a \mathrm{I}$ side should come from the plant genome. Southern blot analysis showed that nontransformed control plants did not possess the ZYMV-CP gene, and plants that were selected by PCR 
contained the ZYMV-CP gene as multiple copies of T-DNA integrated in the plant genome (Figure $1 \mathrm{~B}$ ).

In both experiments, spots on cotyledons, and blisters or spots on leaf blade were absent in nontransgenic control and transgenic T1 or T2 plants. Parental control, and transgenic T1 and T2 plants were diploid, their reproductive systems were monoecious, and the growth habits were runner. Regarding these traits, differences between genotypes were not significant.

In the first experiment, there was no significant difference between transgenic $\mathrm{T} 1$ and control plants concerning stem, branch, leaf, and flower fresh and dry weight parameters (Table 1). Seedling hypocotyl length and leaf blade width of transgenic T1 generation were respectively 22.04 and $7.77 \%$ higher than those of nontransgenic control (Table 2). However, seedling cotyledon width and length of transgenic T1 were 16.95 and $16.48 \%$ lower than those of parental control (Table 2).

In the second experiment, fruit grooving or marbling, patches at hilum were absent, and testa ground color was brown in nontransgenic control or transgenic T2 seeds. The differences between transgenic T2 and nontransgenic control concerning stem, branch, leaf, flower, and fruit parameters (Table 3 and 4), and seed, fresh and dry weight, total yield, and cotyledon parameters (Table 5) were not significant. However, hypocotyl length of transgenic T2 seedling was $8.30 \%$ higher than that of nontransgenic control. Moreover,

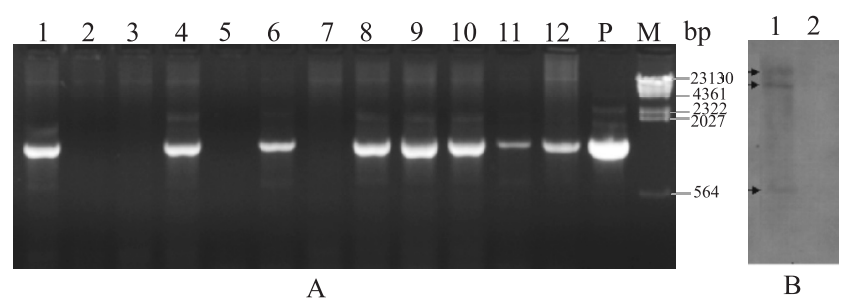

Figure 1. Molecular analysis: A, ethidium bromide stained agarose gel showing the amplification by PCR of the ZYMV-CP gene present in transgenic plants. Samples from transgenic plants (lanes 1, 4, 6 and 8-11), escapee plants (lanes 2, 3, 5 and 7), positive control (lane 12, transgenic watermelon), positive control of pCIB10 plasmid (lane P), and molecular size markers (lane $\mathrm{M}$ ) are indicated. Molecular weight markers (bp) are indicated on the side of the gel. B, Southern blot analysis of T2 progeny. The PCR fragment of ZYMV-CP gene, amplified from the pCIB10, was used as a probe. Total genomic DNA $(10 \mu \mathrm{g})$, from a transformed plant (lane 1) and a nontransformed control plant (lane 2), was digested with $X b a \mathrm{I}$. flesh firmness, size of pistil scar, and flesh color a* value of genetically modified $\mathrm{T} 2$ fruit were respectively $7.19,11.69$ and $8.16 \%$ greater than those of control fruit. Fruit rind thickness and peduncle length of

Table 1. Values of stem, branch, leaf, flower, and fresh and dry weight parameters of nontransgenic 'Crimson Sweet' (CS) watermelon and T1 progeny with transgene ZYMV-CP $(\mathrm{T} 1)^{(1)}$.

\begin{tabular}{|c|c|c|c|}
\hline \multirow[t]{2}{*}{ Parameter } & \multicolumn{2}{|c|}{ Genotype } & \multirow{2}{*}{$\begin{array}{l}\text { CV } \\
(\%)\end{array}$} \\
\hline & $\mathrm{CS}$ & $\mathrm{T} 1$ & \\
\hline Stem thickness (mm) & $10.71 \mathrm{a}$ & $11.22 \mathrm{a}$ & 7.78 \\
\hline Main stem length $(\mathrm{cm})$ & $420.79 a$ & $413.54 \mathrm{a}$ & 6.81 \\
\hline Node number in the main stem & $31.27 \mathrm{a}$ & $29.79 a$ & 4.45 \\
\hline Branch number & $6.36 \mathrm{a}$ & $6.88 \mathrm{a}$ & 12.12 \\
\hline Degree of secondary lobing in leaf blade ${ }^{(2)}$ & $5.42 \mathrm{a}$ & $4.42 \mathrm{a}$ & 16.34 \\
\hline Leaf blade length $(\mathrm{cm})$ & $12.41 \mathrm{a}$ & $12.99 \mathrm{a}$ & 4.92 \\
\hline Leaf area $\left(\mathrm{cm}^{2}\right.$ per plant $)$ & $4,762.70 \mathrm{a}$ & $2,999.00 \mathrm{a}$ & 24.24 \\
\hline Petiole length $(\mathrm{cm})$ & $8.88 \mathrm{a}$ & $8.67 \mathrm{a}$ & 1.16 \\
\hline Node number of the first male flower & $12.00 \mathrm{a}$ & $11.33 \mathrm{a}$ & 6.99 \\
\hline Node number of the first female flower & $15.67 \mathrm{a}$ & $15.00 \mathrm{a}$ & 8.41 \\
\hline Petal height of female flower (mm) & $10.80 \mathrm{a}$ & $11.18 \mathrm{a}$ & 2.86 \\
\hline Petal apex shape of female flower ${ }^{(3)}$ & $5.83 \mathrm{a}$ & $5.29 \mathrm{a}$ & 12.37 \\
\hline Petal width of male $(\mathrm{mm})$ & $24.83 \mathrm{a}$ & $25.24 \mathrm{a}$ & 7.36 \\
\hline Pollen viability (\%) & $93.37 \mathrm{a}$ & $95.30 \mathrm{a}$ & 1.14 \\
\hline Pollen germination (\%) & $75.05 \mathrm{a}$ & $76.42 \mathrm{a}$ & 3.93 \\
\hline Ovary length (mm) & $3.25 \mathrm{a}$ & $3.44 \mathrm{a}$ & 3.27 \\
\hline Ovary width (mm) & $3.50 \mathrm{a}$ & $3.35 \mathrm{a}$ & 5.47 \\
\hline Pubescence of ovary ${ }^{(2)}$ & $4.63 \mathrm{a}$ & $5.13 \mathrm{a}$ & 6.53 \\
\hline Root fresh weight (g per plant) & $32.61 \mathrm{a}$ & $22.45 \mathrm{a}$ & 45.38 \\
\hline Leaf fresh weight (g per plant) & $154.04 \mathrm{a}$ & $92.07 \mathrm{a}$ & 22.55 \\
\hline Shoot fresh weight except leaves (g per plant) & $107.33 \mathrm{a}$ & $64.92 \mathrm{a}$ & 30.96 \\
\hline Root dry weight (g per plant) & $3.16 \mathrm{a}$ & $1.08 \mathrm{a}$ & 72.72 \\
\hline Leaf dry weight (g per plant) & $13.83 \mathrm{a}$ & $9.02 \mathrm{a}$ & 26.72 \\
\hline Shoot dry weight except leaves (g per plant) & $8.33 \mathrm{a}$ & $5.16 \mathrm{a}$ & 39.92 \\
\hline Total fresh weight (g per plant) & $293.98 \mathrm{a}$ & $179.44 \mathrm{a}$ & 27.65 \\
\hline Total dry weight (g per plant) & $25.31 \mathrm{a}$ & $15.26 \mathrm{a}$ & 34.47 \\
\hline
\end{tabular}

${ }^{(1)}$ Means of each parameter followed by equal letters, in the rows, do not differ by LSD test, at 5\% probability. ${ }^{(2)}$ According to the International Union for the Protection of New Varieties of Plants (2004): 3, weak; 5, intermediate; and 7, strong. ${ }^{(3)}$ According to TC Resmi Gazete (1998): 3, acute; 5 , rounded; and 7 , obtuse.

Table 2. Values of seedling and blade parameters of nontransgenic 'Crimson Sweet' (CS) watermelon and T1 progeny with transgene ZYMV-CP (T1) ${ }^{(1)}$.

\begin{tabular}{lrrr}
\hline Parameter $(\mathrm{cm})$ & \multicolumn{2}{c}{ Genotype } & CV \\
\cline { 2 - 3 } & \multicolumn{1}{c}{$\mathrm{CS}$} & $\mathrm{T} 1$ & $(\%)$ \\
\hline Hypocotyl length & $5.40 \mathrm{~b}$ & $6.59 \mathrm{a}$ & 5.21 \\
Cotyledon width & $1.77 \mathrm{a}$ & $1.47 \mathrm{~b}$ & 3.82 \\
Cotyledon length & $2.67 \mathrm{a}$ & $2.23 \mathrm{~b}$ & 6.02 \\
Leaf blade width & $13.52 \mathrm{~b}$ & $14.57 \mathrm{a}$ & 2.62 \\
\hline
\end{tabular}

${ }^{(1)}$ Means of each parameter, followed by equal letters in the rows, do not differ by LSD test, at $5 \%$ probability. 
transgenic T2 individuals were 7.96 and $10.88 \%$ lower than those of control individuals. Stripe color a* value of the nontransgenic control fruit was higher than that of transgenic T2.

Regarding differences between transgenic watermelon line with nontransgenic parental cultivar CS, only four of the 36 characteristics investigated in the first experiment were significant. In the second experiment, only seven out of 80 were significant. The differences between transformed and nontransformed genotypes, with regard to cotyledon width and length or leaf blade width, were not obvious, since the differences were significant in the first experiment (Table 2), but not in the second (Table 3 and 5). This may be attributed to the difference in environmental conditions between the growing seasons (winter-spring and summer-autumn),

Table 3. Values of stem, branch, leaf, and flower parameters of nontransgenic 'Crimson Sweet' (CS) watermelon and T2 progeny with transgene ZYMV-CP (T2) ${ }^{(1)}$.

\begin{tabular}{|c|c|c|c|}
\hline \multirow[t]{2}{*}{ Parameter } & \multicolumn{2}{|c|}{ Genotype } & \multirow{2}{*}{$\begin{array}{l}\text { CV } \\
(\%)\end{array}$} \\
\hline & $\mathrm{CS}$ & $\mathrm{T} 2$ & \\
\hline Stem thickness (mm) & $8.49 \mathrm{a}$ & $8.75 \mathrm{a}$ & 5.05 \\
\hline Main stem length $(\mathrm{cm})$ & $218.17 \mathrm{a}$ & $219.92 \mathrm{a}$ & 2.49 \\
\hline Node numbers in the main stem & $30.50 \mathrm{a}$ & $30.46 \mathrm{a}$ & 5.66 \\
\hline Branch number & $11.38 \mathrm{a}$ & $10.92 \mathrm{a}$ & 3.99 \\
\hline Degree of secondary lobing in leaf blade ${ }^{(2)}$ & $5.79 \mathrm{a}$ & $5.96 \mathrm{a}$ & 3.88 \\
\hline Leaf blade length $(\mathrm{cm})$ & $11.18 \mathrm{a}$ & $11.18 \mathrm{a}$ & 2.89 \\
\hline Leaf blade width $(\mathrm{cm})$ & $10.85 \mathrm{a}$ & $10.92 \mathrm{a}$ & 4.10 \\
\hline Leaf blade color L* value & $42.42 \mathrm{a}$ & $42.16 \mathrm{a}$ & 1.45 \\
\hline Leaf blade color $a^{*}$ value & $-16.94 a$ & $-17.18 \mathrm{a}$ & -15.35 \\
\hline Leaf blade color $b^{*}$ value & $19.18 \mathrm{a}$ & $19.41 \mathrm{a}$ & 21.99 \\
\hline Leaf blade color $C^{*}$ value & $25.62 \mathrm{a}$ & $25.94 \mathrm{a}$ & 19.05 \\
\hline Leaf blade $h^{\circ}$ value & $131.88 \mathrm{a}$ & $132.04 \mathrm{a}$ & 1.52 \\
\hline Leaf area $\left(\mathrm{cm}^{2}\right.$ per plant $)$ & $7,500.00 \mathrm{a}$ & $4,516.00 \mathrm{a}$ & 22.69 \\
\hline Petiole length (cm) & $6.96 a$ & $7.04 \mathrm{a}$ & 6.55 \\
\hline Time of male flowering (day) & $32.25 \mathrm{a}$ & $32.29 \mathrm{a}$ & 1.32 \\
\hline Node number of the first male flower & $10.33 \mathrm{a}$ & $11.00 \mathrm{a}$ & 10.12 \\
\hline Time of female flowering (day) & $32.96 \mathrm{a}$ & $33.21 \mathrm{a}$ & 1.12 \\
\hline Node number of the first female flower & $14.67 \mathrm{a}$ & $15.00 \mathrm{a}$ & 5.50 \\
\hline Petal height of female flower (mm) & $10.70 \mathrm{a}$ & $10.90 \mathrm{a}$ & 3.92 \\
\hline Petal apex shape of female flower ${ }^{(3)}$ & $5.71 \mathrm{a}$ & $5.42 \mathrm{a}$ & 3.04 \\
\hline Petal width of male (mm) & $19.60 \mathrm{a}$ & $19.04 \mathrm{a}$ & 4.05 \\
\hline Pollen viability (\%) & $92.60 \mathrm{a}$ & $93.53 \mathrm{a}$ & 1.27 \\
\hline Pollen germination (\%) & $68.12 \mathrm{a}$ & $78.57 \mathrm{a}$ & 7.50 \\
\hline Ovary length (mm) & $2.95 \mathrm{a}$ & $2.97 \mathrm{a}$ & 3.76 \\
\hline Ovary width (mm) & $3.40 \mathrm{a}$ & $3.43 \mathrm{a}$ & 4.44 \\
\hline Pubescence of ovary ${ }^{(2)}$ & $5.17 \mathrm{a}$ & $5.25 \mathrm{a}$ & 7.06 \\
\hline
\end{tabular}

${ }^{(1)}$ Means followed by equal letters, in the rows, do not differ by LSD test, at $5 \%$ probability. ${ }^{(2)}$ According to the International Union for the Protection of New Varieties of Plants (2004): 3, weak; 5, intermediate; and 7, strong. ${ }^{(3)}$ According to TC Resmi Gazete (1998): 3, acute; 5, rounded; and 7 , obtuse. when the experiments were carried out. It has been reported that three profiling technologies were used to compare two transgenic maize lines with the respective control line, and the effect of growing conditions as an additional environmental effect was also evaluated by comparing the Bt-maize line with the control line, in three different locations in one growing season (Barros et al., 2010). The authors have concluded that environmental factors caused more variation in different transcript/protein/metabolite profiles than the genotypes.

In both experiments, in the present work, hypocotyl length of transgenic watermelon seedlings was significantly higher than that of the nontransgenic parental ones (Table 2 and 5). In the second experiment, the differences between transgenic and nontransgenic

Table 4. Values of fruit parameters of nontransgenic 'Crimson Sweet' (CS) watermelon and T2 progeny with transgene ZYMV-CP (T2) ${ }^{(1)}$.

\begin{tabular}{|c|c|c|c|}
\hline \multirow[t]{2}{*}{ Fruit parameter } & \multicolumn{2}{|c|}{ Genotype } & \multirow{2}{*}{$\begin{array}{l}\text { CV } \\
(\%) \\
\end{array}$} \\
\hline & $\mathrm{CS}$ & $\mathrm{T} 2$ & \\
\hline Shape $^{(2)}$ & $2.52 \mathrm{a}$ & $2.65 \mathrm{a}$ & 6.09 \\
\hline Width (cm) & $13.24 \mathrm{a}$ & $13.24 \mathrm{a}$ & 3.81 \\
\hline Length (cm) & $14.52 \mathrm{a}$ & $13.32 \mathrm{a}$ & 4.68 \\
\hline Weight (kg) & $1.42 \mathrm{a}$ & $1.24 \mathrm{a}$ & 9.86 \\
\hline Shape of apical part ${ }^{(3)}$ & $3.67 \mathrm{a}$ & $3.77 \mathrm{a}$ & 6.84 \\
\hline Shape of basal part ${ }^{(3)}$ & $3.54 \mathrm{a}$ & $3.69 \mathrm{a}$ & 6.30 \\
\hline Peduncle diameter $(\mathrm{mm})$ & 7.44a & $7.65 \mathrm{a}$ & 1.97 \\
\hline Size of insertion of peduncle (mm) & $15.82 \mathrm{a}$ & $16.07 \mathrm{a}$ & 0.92 \\
\hline Ground color $L^{*}$ value & $66.04 \mathrm{a}$ & $64.87 \mathrm{a}$ & 2.52 \\
\hline Ground color a* value & $-16.27 \mathrm{a}$ & $-18.07 \mathrm{a}$ & -5.36 \\
\hline Ground color b* value & $26.06 \mathrm{a}$ & $28.27 \mathrm{a}$ & 3.61 \\
\hline Ground color $C^{*}$ value & $30.78 \mathrm{a}$ & $33.23 \mathrm{a}$ & 4.35 \\
\hline Ground color $\mathrm{h}^{\mathrm{o}}$ value & $122.00 \mathrm{a}$ & $122.62 \mathrm{a}$ & 0.66 \\
\hline Stripe color L* value & $41.65 \mathrm{a}$ & $41.23 \mathrm{a}$ & 2.91 \\
\hline Stripe color b* value & $20.90 \mathrm{a}$ & $23.25 \mathrm{a}$ & 5.39 \\
\hline Stripe color $C^{*}$ value & $26.58 \mathrm{a}$ & $29.30 \mathrm{a}$ & 4.57 \\
\hline Stripe color $\mathrm{h}^{\mathrm{o}}$ value & $128.49 \mathrm{a}$ & $127.67 \mathrm{a}$ & 0.73 \\
\hline Flesh color $\mathrm{L}^{*}$ value & $42.70 \mathrm{a}$ & $42.46 \mathrm{a}$ & 4.33 \\
\hline Flesh color $b^{*}$ value & $14.94 \mathrm{a}$ & $16.00 \mathrm{a}$ & 6.38 \\
\hline Flesh color $\mathrm{C}^{*}$ value & $23.45 \mathrm{a}$ & $25.24 \mathrm{a}$ & 3.45 \\
\hline Flesh color $\mathrm{h}^{\mathrm{o}}$ value & $39.44 a$ & $39.21 \mathrm{a}$ & 3.54 \\
\hline Malic acid (\%) & $0.1477 \mathrm{a}$ & $0.1483 a$ & 1.32 \\
\hline Total soluble solid ( ${ }^{\circ}$ Brix) & $7.17 \mathrm{a}$ & $7.62 \mathrm{a}$ & 7.41 \\
\hline $\mathrm{pH}$ & $5.14 \mathrm{a}$ & $5.16 \mathrm{a}$ & 0.52 \\
\hline
\end{tabular}

${ }^{(1)}$ Means of each parameter, followed by equal letters in the rows, do not differ by LSD test, at $5 \%$ probability. ${ }^{(2)}$ According to the European Cooperative Programme for Plant Genetic Resources (2008): 1, flattened; 2, round; 3, broad elliptical; 4, elliptical; 5, pyriform; and 6, oblong. ${ }^{(3)}$ According to TC Resmi Gazete (1998) and the International Union for the Protection of New Varieties of Plants (2004): 1, flat; 2, flat to rounded; 3, rounded; 4, rounded to conical; and 5, conical. 
individuals were significant, concerning fruit rind thickness, flesh firmness, fruit peduncle length, size of pistil scar, and fruit flesh or stripe color $a^{*}$ values (Table 5). The variation in size of pistil scar in the transgenic line was undesirable. However, variations in some characteristics of the transgenic genotype were favorable, since they were related to fruit with less rind thickness, more flesh firmness and higher flesh color $a^{*}$ value. The differences between the transgenic watermelon line and its nontransformed originating cultivar may be a result of pleiotropic effect of transgenes, as reported by Montero et al. (2011).

Our results are consistent with previous publications available in the literature indicating high similarity of the transgenic genotypes to their nontransgenic counterparts. Jiao et al. (2010) have revealed that the transgenic papaya composition showed great similarity to the nontransgenic cultivar. Venneria et al. (2008) showed that nutritional values of transgenic genotypes were similar to nontransgenic control cultivars of wheat, corn, and tomato. No significant differences were reported between transgenic (with ZYMV-CP) and control melon genotypes, with regard to L-ascorbic

Table 5. Values for parameters of seed, fresh and dry weight, total yield, seedling and fruit of nontransgenic 'Crimson Sweet' (CS) watermelon and T2 progeny with transgene ZYMV-CP (T2) $)^{(1)}$.

\begin{tabular}{|c|c|c|c|}
\hline \multirow[t]{2}{*}{ Parameter } & \multicolumn{2}{|c|}{ Genotype } & \multirow{2}{*}{$\begin{array}{l}\text { CV } \\
(\%)\end{array}$} \\
\hline & $\mathrm{CS}$ & $\mathrm{T} 2$ & \\
\hline Number of seeds per fruit & $66.86 \mathrm{a}$ & $46.02 \mathrm{a}$ & 38.40 \\
\hline Seed mean weight (mg per seed) & $29.57 \mathrm{a}$ & $28.32 \mathrm{a}$ & 6.23 \\
\hline Root fresh weight (g per plant) & $29.70 \mathrm{a}$ & $33.45 \mathrm{a}$ & 31.12 \\
\hline Leaf fresh weight (g per plant) & $157.36 \mathrm{a}$ & $135.55 \mathrm{a}$ & 18.47 \\
\hline Shoot fresh weight except leaves (g per plant) & $225.95 \mathrm{a}$ & $219.32 \mathrm{a}$ & 16.60 \\
\hline Root dry weight (g per plant) & $1.60 \mathrm{a}$ & $1.37 \mathrm{a}$ & 28.99 \\
\hline Leaf dry weight (g per plant) & $13.17 \mathrm{a}$ & $12.64 \mathrm{a}$ & 24.63 \\
\hline Shoot dry weight except leaves (g per plant) & $13.47 \mathrm{a}$ & $12.20 \mathrm{a}$ & 27.04 \\
\hline Total fresh weight (g per plant) & $413.01 \mathrm{a}$ & $388.31 \mathrm{a}$ & 18.32 \\
\hline Total dry weight (g per plant) & $28.24 \mathrm{a}$ & $26.22 \mathrm{a}$ & 24.36 \\
\hline Total yield $\left(\mathrm{kg} \mathrm{m}^{-2}\right)$ & $1.90 \mathrm{a}$ & $1.68 \mathrm{a}$ & 10.53 \\
\hline Cotyledon width (cm) & $1.71 \mathrm{a}$ & $1.77 \mathrm{a}$ & 3.44 \\
\hline Cotyledon length (cm) & $2.14 \mathrm{a}$ & $2.38 \mathrm{a}$ & 4.81 \\
\hline Hypocotyl length (cm) & $4.94 b$ & $5.35 \mathrm{a}$ & 2.64 \\
\hline Fruit rind thickness (mm) & $7.79 \mathrm{a}$ & $7.17 b$ & 3.08 \\
\hline Fruit flesh firmness (Newton) & $7.23 b$ & $7.75 \mathrm{a}$ & 2.13 \\
\hline Fruit peduncle length $(\mathrm{cm})$ & $2.39 \mathrm{a}$ & $2.13 b$ & 3.57 \\
\hline Size of pistil scar (mm) & $6.50 \mathrm{~b}$ & $7.26 \mathrm{a}$ & 4.64 \\
\hline Fruit flesh color $a^{*}$ value & $18.02 b$ & $19.49 \mathrm{a}$ & 1.58 \\
\hline Fruit stripe color a* value & $-16.39 a$ & $-17.82 b$ & -3.57 \\
\hline
\end{tabular}

acid, malic acid, citric acid, sucrose, glucose, fructose (Yalçin-Mendi et al., 2010). However, these authors have shown that fruit total acidity was significantly different in transgenic and control melon genotypes. According to Baudo et al. (2006) and Shewry et al. (2007), the genetic modification has a lower effect on the transcriptome of the wheat grain compared to traditional breeding. Coll et al. (2009) showed that the gene expression profiles of maize (MON810) and comparable non-genetically modified maize varieties cultured in the field are more similar than those of conventional lines.

Some reports in the literature indicate that there are great similarities between transgenic genotypes transformed with one or two intended transgenes, and nontransgenic parental lines (Baudo et al., 2006; Shewry et al., 2007; Venneria et al., 2008; Coll et al., 2009; Barros et al., 2010). However, when more than two intended genes or transcriptional factor genes are transferred to a plant genome, the similarity of transformed and nontransformed counterpart may not be so great, what demands a careful study, as reported by Batista et al. (2008). Based on the results reported here, it is not possible to conclude that all transgenic and nontransgenic crops are very similar; however, it is possible to produce transgenic genotypes which have a great similarity with their originating conventional cultivars.

\section{Conclusions}

1. Transferring Zucchini yellow mosaic virus coat protein (ZYMV-CP) gene to watermelon cultivar Crimson Sweet (CS) via Agrobacterium tumefaciens affects only a few traits from the 80 investigated ones.

2. Changes in rind thickness, flesh firmness, and flesh color a* value are favorable, while size of pistil scar is undesirable.

3. The transgenic watermelon line containing ZYMV-CP gene and its parental cultivar CS are very similar.

\section{Acknowledgements}

To the State Planning Organization (Turkey), the Scientific and Technological Research Council of Turkey, and the Mustafa Kemal University (Antakya, Turkey), for funding; to Prof. Rebecca Grumet and the Michigan State University, for generously providing 
A. tumefaciens EHA 105 with pCIB10, containing NPTII and ZYMV-CP genes, and for sharing the laboratory during the transformation experiments; and to Dr. Metin Tuna, for determination of the ploidy level of the nontransgenic control and transgenic watermelon plants by flow cytometry.

\section{References}

AMMANN, K. Molecular differences between GM- and non-GM crops over-estimated? Nepal Journal of Biotechnology, v.1, p.31-48, 2011.

ARUMUGANATHAN, K.; EARLE, E.D. Estimation of nuclear DNA content of plants by flow cytometry. Plant Molecular Biology Reporter, v.9, p.229-241, 1991.

BARROS, E.; LEZAR, S.; ANTTONEN, M.J.; DIJK, J.P.V.; RÖHLIG, R.M.; KOK, E.J.; ENGEL, K.H. Comparison of two GM maize varieties with a near-isogenic non-GM variety using transcriptomics, proteomics and metabolomics. Plant Biotechnology Journal, v.8, p.436-451, 2010.

BATISTA, R.; SAIBO, N.; LOURENC, T.; OLIVEIRA, M.M. Microarray analyses reveal that plant mutagenesis may induce more transcriptomic changes than transgene insertion. Proceedings of the National Academy of Sciences of the United States of America, v.105, p.3640-3645, 2008.

BAUDO, M.M.; LYONS, R.; POWERS, S.; PASTORI, G.M.; EDWARDS, K.J.; HOLDSWORTH, M.J.; SHEWRY, P.R. Transgenesis has less impact on the transcriptome of wheat grain than conventional breeding. Plant Biotechnology Journal, v.4, p.369-380, 2006.

CATCHPOLE, G.S.; BECKMANN, M.; ENOT, D.P.; MONDHE, M.; ZYWICKI, B.; TAYLOR, J.; HARDY, N.; SMITH, A.; KING, R.D.; KELL, D.B.; FIEHN, O.; DRAPER, J. Hierarchical metabolomics demonstrates substantial compositional similarity between genetically modified and conventional potato crops. Proceedings of the National Academy of Sciences of the United States of America, v.102, p.14458-14462, 2005.

COLL, A.; NADAL, A.; COLlADO, R.; CAPELLADES, G.; MESSEGUER, J.; MELÉ, E.; PALAUDELMÀS, M.; PLA, M. Gene expression profiles of MON810 and comparable non-GM maize varieties cultured in the field are more similar than are those of conventional lines. Transgenic Research, v.18, p.801-808, 2009.

COMPTON, M.E.; GRAY, D.J. Shoot organogenesis and plant regeneration from cotyledons of diploid, triploid, and tetraploid watermelon. Journal of American Society for Horticultural Science, v.118, p.151-157, 1993.

ÇÜRÜK, S.; ÇETINER, S.; ELMAN, C.; XIA, X.; WANG, Y.; YEHESKEL,A.;ZILBERSTEIN,L.; PERL-TREVES, R.; WATAD, A.A.; GABA, V. Transformation of recalcitrant melon (Cucumis melo L.) cultivars is facilitated by wounding with carborundum. Engineering in Life Sciences, v.5, p.169-177, 2005.
ÇÜRÜK, S.; DASGAN, H.Y.; MANSUROĞLU, S.; KURT, Ş.; MAZMANOĞLU, M.; ANTAKLI, Ö.; TARLA, G. Grafted eggplant yield, quality and growth in infested soil with Verticillium dahliae and Meloidogyne incognita. Pesquisa Agropecuária Brasileira, v.44, p.1673-1681, 2009.

EUROPEAN COOPERATIVE PROGRAMME FOR PLANT GENETIC RESOURCES. Minimum descriptors for Cucurbita spp., cucumber, melon and watermelon. 2008. Available at: <http://www.ecpgr.cgiar.org/fileadmin/www.ecpgr. cgiar.org/NW_and_WG_UPLOADS/Cucurbits_DescriptorLists. pdf $>$. Accessed on: 11 Aug. 2011.

FANG, G.W.; GRUMET, R. Genetic engineering of potyvirus resistance using constructs derived from the Zucchini yellow mosaic virus coat protein gene. Molecular Plant-Microbe Interactions, v.6, p.358-367, 1993.

FOOD AND AGRICULTURE ORGANIZATION. Joint FAO/ WHO expert consultation on biotechnology and food safety. Rome: FAO: WHO, 1996. 26p.

GUSMINI, G.; WEHNER, T.C. Watermelon crops information: extraction of DNA from watermelon leaves. 2010. Available at: $\quad<$ http://cuke.hort.ncsu.edu/cucurbit/wmelon/wmhndbk/ wmgsbdna.html $>$. Accessed on: 4 Jan. 2010.

HELMS, C. Alkaline lysis minipreps of plasmid or cosmid DNA. 1990. Available at: <http://humgen.wustl.edu/hdk_lab_manual/ plasmid/plsmid05.html>. Accessed on: 3 June 2010.

INTERNATIONAL SERVICE FOR THE ACQUISITION OF AGRI-BIOTECH APPLICATIONS. Global status of commercialized Biotech/GM crops: 2010. Ithaca: ISAAA, 2010. (ISAAA Brief, 42. Executive summary). Available at: <http://www.isaaa.org/resources/publications/briefs/42/ executivesummary/default.asp >. Accessed on: 11 Aug. 2011.

INTERNATIONAL UNION FOR THE PROTECTION OF NEW VARIETIES OF PLANTS. Guidelines for the conduct of tests for distinctness, uniformity and stability: Watermelon (Citrullus lanatus (Thunb.) Matsum. et Nakai). Geneva: UPOV, 2004. 36p. (UPOV. TG/142/4).

JIAO, Z.; DENG, J.; LI, G.; ZHANG, Z.; CAI, Z. Study on the compositional differences between transgenic and non-transgenic papaya (Carica papaya L.). Journal of Food Composition and Analysis, v.23, p.640-647, 2010.

LEVI, A.; THOMAS, C. An improved procedure for isolation of high quality DNA from watermelon and melon leaves. Cucurbit Genetics Cooperative Report, v.22, p.41-42, 1999.

MCGUIRE, R.G. Reporting of objective color measurements. HortScience, v.27, p.1254-1255, 1992.

MONTERO, M.; COLL, A.; NADAL, A.; MESSEGUER, J.; PLA, M. Only half the transcriptomic differences between resistant genetically modified and conventional rice are associated with the transgene. Plant Biotechnology Journal, v.9, p.693-702, 2011.

MURASHIGE, T.; SKOOG, F. A revised medium for rapid growth and bio assays with tobacco tissue cultures. Physiologia Plantarum, v.15, p.473-497, 1962. 
ORGANISATION FOR ECONOMIC CO-OPERATION AND DEVELOPMENT. Safety evaluation of foods derived by modern biotechnology: concepts and principles. Paris: OECD, 1993. 79p.

SADLER, G.O. Titratable acidity. In: NIELSEN, S.S. (Ed.). Introduction to the chemical analysis of foods. Boston: Jones and Bartlett, 1994. p.81-91.

SAS INSTITUTE. SAS OnlineDoc. Version 8. Cary: SAS Institute, 1999. Available at: $<$ http://v8doc.sas.com/sashtml/>. Accessed on: 25 Aug. 2010.

ŞENSOY A.S.; ERCAN, N.; AYAR, F.; TEMIRKAYNAK, $M$. The evaluation of pollen viability and the determine some pollen characteristics in some species of Cucurbitaceae family. Akdeniz Üniversitesi Ziraat Fakültesi Dergisi, v.16, p.1-6, 2003.

SHEWRY, P.R.; BAUDO, M.; LOVEGROVE, A.; POWERS, S.; NAPIER, J. A.; WARD, J.L.; BAKER, J.M.; BEALE, M.H. Are
GM and conventionally bred cereals really different? Trends in Food Science and Technology, v.18, p.201-209, 2007.

TC RESMI GAZETE. Official Gazette of Republic of Turkey. Karpuz (Citrullus lanatus (Thunb.). 1998. Available at: $<$ http://www.resmigazete.gov.tr/main.aspx?home=http:// www.resmigazete.gov.tr/arsiv/23491.pdf\&main=http://www. resmigazete.gov.tr/arsiv/23491.pdf $>$. Accessed on: 11 Aug. 2011.

VENNERIA, E.; FANASCA, S.; MONASTRA, G.; FINOTTI, E.; AMBRA, R.; AZZINI, E.; DURAZZO, A.; FODDAI, M.S.; MAIANI, G. Assessment of the nutritional values of genetically modified wheat, corn, and tomato crops. Journal of Agricultural and Food Chemistry, v.56, p.9206-9214, 2008.

YALÇIN-MENDI, Y.; SARI, N.; AKYILDIZ, A.; SOLMAZ, İ.; ÜNEK, C.; ÖZKAYA, O.; SERÇE, S. Determination of gene escape and fruit quality characteristics in transgenic melon (Cucumis melo L. var. inodorus). Turkish Journal of Agriculture and Forestry, v.34, p.135-143, 2010.

Received on August 30, 2011 and accepted on December 30, 2011 